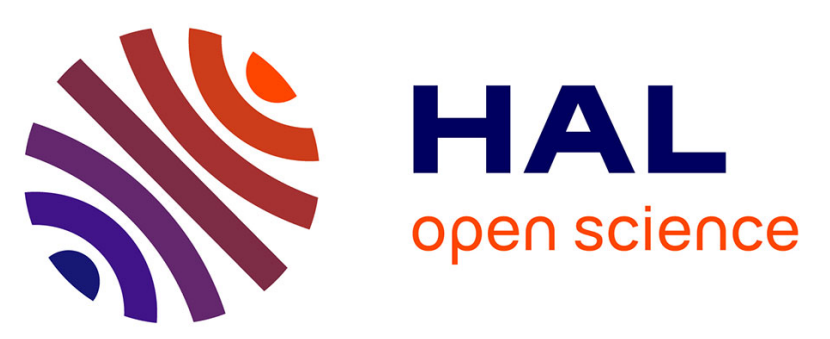

\title{
Foraging ecology of five toothed whale species in the Northwest Iberian Peninsula, inferred using carbon and nitrogen isotope ratios
}

\author{
Paula Méndez-Fernandez, Paco Bustamante, Antonio Bode, Tiphaine
} Chouvelon, Marisa Ferreira, Alfredo Lopez, Graham J. Pierce, Maria Begoña

Santos, Jérôme Spitz, José Vingada, et al.

\section{To cite this version:}

Paula Méndez-Fernandez, Paco Bustamante, Antonio Bode, Tiphaine Chouvelon, Marisa Ferreira, et al.. Foraging ecology of five toothed whale species in the Northwest Iberian Peninsula, inferred using carbon and nitrogen isotope ratios. Journal of Experimental Marine Biology and Ecology, 2011, 413, pp.150-158. 10.1016/j.jembe.2011.12.007 . hal-00842286

\section{HAL Id: hal-00842286 https://hal.science/hal-00842286}

Submitted on 11 Jul 2013

HAL is a multi-disciplinary open access archive for the deposit and dissemination of scientific research documents, whether they are published or not. The documents may come from teaching and research institutions in France or abroad, or from public or private research centers.
L'archive ouverte pluridisciplinaire HAL, est destinée au dépôt et à la diffusion de documents scientifiques de niveau recherche, publiés ou non, émanant des établissements d'enseignement et de recherche français ou étrangers, des laboratoires publics ou privés. 
Foraging ecology of five toothed whale species in the Northwest Iberian Peninsula, inferred using carbon and nitrogen isotope ratios.

Paula Mèndez-Fernandez ${ }^{\text {a,b,c,* }}$, Paco Bustamante ${ }^{a}$, Antonio Bode ${ }^{\mathrm{d}}$, Tiphaine Chouvelon ${ }^{\mathrm{a}}$, Marisa Ferreira ${ }^{\mathrm{c}}$, Alfredo López ${ }^{\mathrm{b}}$, Graham J. Pierce ${ }^{\mathrm{e}, \mathrm{f}}$, M. Begoña Santos ${ }^{\mathrm{f}}$, Jérôme Spitz ${ }^{\mathrm{a}}$, José V. Vingada $^{c}$, Florence Caurant ${ }^{\mathrm{a}}$

${ }^{\text {a }}$ Littoral Environnement et Sociétés (LIENSs), UMR 6250, CNRS-Université de La Rochelle, 2 rue Olympe de Gouges 17042 La Rochelle Cedex 01, France

${ }^{\mathrm{b}}$ CEMMA, Apdo. 15, Pontevedra, 36380, Spain

${ }^{c}$ CBMA / SPVS, Dep. de Biologia, Universidade do Minho, Campus de Gualtar, Braga, 4710-057, Portugal

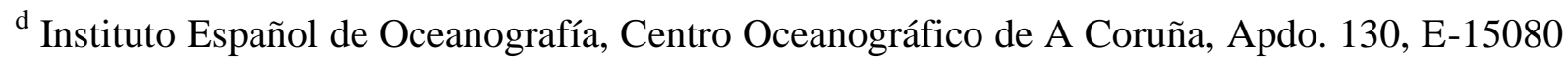
A Coruña, Spain

${ }^{\mathrm{e}}$ Oceanlab, University of Aberdeen Main Street, Newburgh, Aberdeenshire, AB41 6AA, UK

${ }^{\mathrm{f}}$ Instituto Español de Oceanografía, Centro Oceanográfico de Vigo, Apdo. 1552, E-36280 Vigo, Spain

*Corresponding author. Tel.: +33 5 46458388; fax: +33 546496711

E-mail addresses: paula.mendez_fernandez@univ-lr.fr 


\section{ABSTRACT}

The feeding ecology and habitat use of the most frequently sighted and/or regularly reported stranded or by-caught toothed whale species of the North Western Iberian Peninsula (NWIP) were examined, with a special focus on their trophic position (TP) and relationships with their prey. With this aim, the stable isotope ratios of carbon $\left(\delta^{13} \mathrm{C}\right)$ and nitrogen $\left(\delta^{15} \mathrm{~N}\right)$ of common dolphin (Delphinus delphis), bottlenose dolphin (Tursiops truncatus), harbour porpoise (Phocoena phocoena), striped dolphin (Stenella coeruleolba) and long-finned pilot whale (Globicephala melas) were analyzed in muscle samples taken from stranded and by caught animals between 2004 and 2008. Stable isotopes were also measured in 17 species of fish and cephalopods previously identified as prey species, based on stomach content analyses, and in plankton. The trophic enrichment factors (TEF) were calculated for all five species and in addition, isotopic mixing models were applied to estimate the proportional contribution of each prey source to the diet of the common dolphin, which was the toothed whale species best sampled in our study. Plankton, fish and cephalopods exhibited an increasing trend in their $\delta^{13} \mathrm{C}$ values (from $-19.6 \%$ to $-15.3 \%$ ) along the offshore-inshore axis, with a less clear spatial pattern observed for $\delta^{15} \mathrm{~N}$ values. Striped dolphins exhibited the lowest mean $\delta^{13} \mathrm{C}, \delta^{15} \mathrm{~N}$ and TP values (-17.6\%o, 10.8\%o and 4.3, respectively), which confirms the oceanic character of this species and its lower trophic position when compared to the other toothed whales analyzed. The common dolphin exhibited mean $\delta^{13} \mathrm{C}, \delta^{15} \mathrm{~N}$ and TP values that were at an intermediate level $(-17.0 \%$, $11.7 \%$ and 4.7 , respectively) and results of the mixing model indicated that blue whiting (Micromesistius poutassou) was the main component of the diet. The harbour porpoise, bottlenose dolphin and pilot whale exhibited higher and very similar isotopic compositions and TPs. The mean TEF obtained between predators and their main prey were $1.4 \%$ for $\delta^{15} \mathrm{~N}$ and $0.8 \%$ for $\delta^{13} \mathrm{C}$. These results provide information on stable 
isotope incorporation data for toothed whales, which are essential if conclusions are to be drawn in issues concerning trophic structures and habitat use in the NWIP.

KEY WORDS: Stable isotopes • Toothed whales • Trophic position • Trophic relationships • Isotopic mixing model $\cdot$ North West Iberian Peninsula 


\section{INTRODUCTION}

Marine mammals are recognized as top predators in marine trophic webs but little is known about their role in the structuring of marine ecosystems (Bowen 1997). The main limitation is that the ecological needs of such large animals often exceed the temporal and spatial scales used to define community boundaries. This role is especially important in habitats with enhanced productivity such as upwelling areas, where high species richness contributes to high trophic linkage density and exceptional resource abundance (Bode et al. 2003). This is the case of the Northwest Iberian Peninsula (NWIP) waters. This area is characterized by high marine biodiversity and productivity, supported by strong nutrient enrichment during seasonal upwelling periods (Fraga 1981), and a relatively narrow (20-35 km wide) shelf. From April to September, the prevalent northerly winds favor the upwelling of the nutrient-rich Eastern North Atlantic Central Water (Fraga 1981), sustaining a high level of productivity when compared to adjacent areas. The marine fauna of the NWIP includes at least 19 marine mammal species (16 cetaceans and 3 pinnipeds; López et al. 2002). Based on strandings and sightings data, the most common cetacean species are all toothed whales: common dolphin (Delphinus delphis), bottlenose dolphin (Tursiops truncatus), harbour porpoise (Phocoena phocoena), long-finned pilot whale (Globicephala melas), striped dolphin (Stenella coeruleoalba) and Rissos's dolphin (Grampus griseus) (López et al. 2002, 2004, Pierce et al. 2010). Despite the high proportion of cetaceans inhabiting the NWIP little is known about their role into the food web and their trophic relationships. Knowledge of feeding habits, habitat use and trophic relationships within a community is needed to underpin sound management measures, in particular in areas such as the NIWP where fishery by-catch mortality (López et al. 2002, 2003), prey depletion due to overfishing, and oil spills (Ridoux et al. 2004) are the main threats to cetacean populations. 
Previous studies based on stomach contents analyses, have investigated the diet of the five toothed whales in the NWIP. Striped dolphin and pilot whale are known to be mainly cephalopods eaters. However striped dolphin exhibits dietary plasticity since some crustacean species, oceanic fish such as silvery lightfish (Maurolicus muelleri) as well as pelagic fish species (e.g. scad Trachurus trachurus, sand smelt Atherina presbyter) were found in stomach contents of individuals stranded in the NWIP (Spitz et al. 2006, Sollmann 2011). Common dolphin mainly feeds on fish species, and the blue whiting (Micromesistius poutassou), sardine (Sardina pilchardus) and sand smelt are the most important prey species in the studied area (Santos et al. 2004c). Bottlenose dolphins have a varied diet in the NIWP, although it was strongly dominated by blue whiting and hake (Merluccius merluccius) (Santos et al. 2007a,b). Finally harbour porpoise from the NWIP manly feeds on pelagic and coastal fish species such as pouting (Trisopterus luscus) and scad (Santos et al. 2004a, Pierce et al. 2010). These differences in diet are also supported by differences in habitat uses (Pierce et al. 2010) and could thus lead to segregation among the five toothed whale species in the area. However, it is widely recognized that stomach content analyses have a number of limitations, since information provided by stomach contents normally allows the identification of the prey consumed shortly before the stomachs were collected (Pierce \& Boyle 1991) and varying time of digestion of different prey species can result in a overestimation of some species (Santos et al. 2001). Thus, insights into the trophic relationships and feeding habits of marine mammals can be obtained by measuring the ratios of naturally occurring isotopes such as those of carbon and nitrogen, in specific tissues (Hobson \& Welch 1992, Ostrom et al. 1993, Muir et al. 1995). This chemical analysis constitutes a powerful complementary method to the stomach content analyses, and is based on the assumption that predator stable isotope compositions are a reflection of those of their prey (DeNiro \& Epstein 1978, 1981). Ratios of the natural abundance of stable isotopes of carbon $\left(\delta^{13} \mathrm{C}\right)$ and nitrogen $\left(\delta^{15} \mathrm{~N}\right)$ have been 
extensively used in studies of cetacean ecology to assess dietary variation in space and time (Abend \& Smith 1995, Méndes et al. 2007, Knoff et al. 2008). Turnover rates vary among tissues depending on their metabolic activity, e.g. faster turnover rates have been measured for skin than for teeth (Walker \& Macko 1999). The difference in turnover rates between tissues allows the exploration of the dietary history of individual animals over different time windows from few days to several years (Abend \& Smith 1995). In addition to information on diet, $\delta^{13} \mathrm{C}$ and $\delta^{15} \mathrm{~N}$ signatures can act as chemical tracers that reflect characteristics of the ecosystem where an animal forages, to determine the trophic position of species in marine food webs (Fry \& Sherr 1984, Bode et al. 2003, 2007) but also to study migration patterns (see Hobson 1999 for review) and population substructure (Borrell et al. 2006). Stable isotopes of carbon and nitrogen show enrichment (an increase in the abundance of the heavier isotope) through food webs with increasing trophic level. The enrichment of $\delta^{13} \mathrm{C}$ is generally small or insignificant (DeNiro \& Epstein 1978, Vander Zanden \& Rasmussen 2001) and, therefore, $\delta^{13} \mathrm{C}$ is primarily used to provide information on the origin of the base of the food chain (France 1995) and can reveal information such as inshore vs offshore feeding preferences (Hobson \& Welch 1992). On the other hand, $\delta^{15} \mathrm{~N}$ enrichment per trophic level in marine food webs is normally considerably higher, with an estimated mean trophic enrichment factor (TEF) ranging from 2 to 5\% (DeNiro \& Epstein 1978, 1981, Hobson \& Welch 1992, Vander Zanden \& Rasmussen 2001). Nitrogen isotope ratios are thus more useful as an indicator of trophic position although some variability of $\delta^{15} \mathrm{~N}$ has also been demonstrated, for example an inshore $v s$ offshore enrichment of $\delta^{15} \mathrm{~N}$ signatures (Chouvelon et al. in press) due to the use of different nitrogen sources by phytoplankton. TEF also vary depending on the tissue analyzed (Hobson et al. 1996). For example, metabolically active tissues show less enrichment in $\delta^{13} \mathrm{C}$ ( or $\delta^{15} \mathrm{~N}$ ) relative to the diet than inactive or keratinous tissues (Hobson et al. 1996). This represents a potential confounding factor when using 
isotope ratios in different tissues to infer information on feeding ecology over different time periods.

In this context, the aim of the present study was to investigate the feeding ecology and habitat use of five toothed whales species inhabiting the NWIP waters through the use of stable isotopes analysis $\left(\delta^{13} \mathrm{C}\right.$ and $\left.\delta^{15} \mathrm{~N}\right)$ and based on previous stomach content studies. The carbon and nitrogen isotope ratios of known prey species (eight fish species and nine cephalopod species; see below for details) and plankton (selected as the base of the food web in the research area) were also analyzed, in order to position the predators and their potential prey in the food web and to study their trophic relationships. Following this aim, the TEF of toothed whales and prey species were calculated. For the common dolphin, which is the most abundant cetacean species in the Iberian Peninsula and also the best represented in the samples available, isotopic mixing models were also applied to estimate the proportional contribution of each prey source to its diet.

\section{MATERIALS AND METHODS}

\section{Sample collection}

The fieldwork was carried out in the North West of the Iberian Peninsula, in an area extending from the northern limit of the Galician coast $\left(43^{\circ} 31^{\prime} \mathrm{N}, 7^{\circ} 2^{\prime} \mathrm{W}\right)$ to Nazare on the

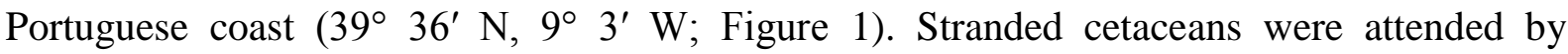
experienced personnel of the Galician (Coordinadora para o Estudo dos Mamiferos Mariños, CEMMA) or Portuguese (Sociedade Portuguesa de Vida Salvagem, SPVS) stranding networks. Animals were identified to species, measured, sexed and, if the state of preservation of the carcass allowed it, full necropsies were performed and samples collected following a standard protocol defined by the European Cetacean Society (after Kuiken 1996). For this study, between 2004 and 2008, muscle tissues were sampled from stranded and by-caught 
individuals of five toothed whale species: common dolphin $(n=114)$, bottlenose dolphin $(n=$ 9), harbour porpoise $(n=19)$, striped dolphin $(n=21)$ and long-finned pilot whale $(n=9)$ (see Table 1). After collection, muscle samples were stored at $-20{ }^{\circ} \mathrm{C}$ until processed in the laboratory.

Muscle tissues of 17 species of fish and cephalopods previously identified in the literature as prey of the sampled cetacean species in the study area (see Santos et al. 2004a,c, 2007a,b) were also analyzed (see Table 2). All the fish samples and those of common squid (Loligo vulgaris) were collected with a pelagic trawl, during the PELACUS0409 survey. This survey, carried out by Instituto Español de Oceanografía (IEO) in spring 2009 aimed to acoustically assess pelagic marine living resources of northwestern and northern Spanish shelf waters. Plankton was also collected during the survey, at night by vertical tows ( $0-100 \mathrm{~m}$ depth) of a conical net deployed at regularly distributed stations over the shelf up to the shelf-break throughout the surveyed area (Figure 1). 


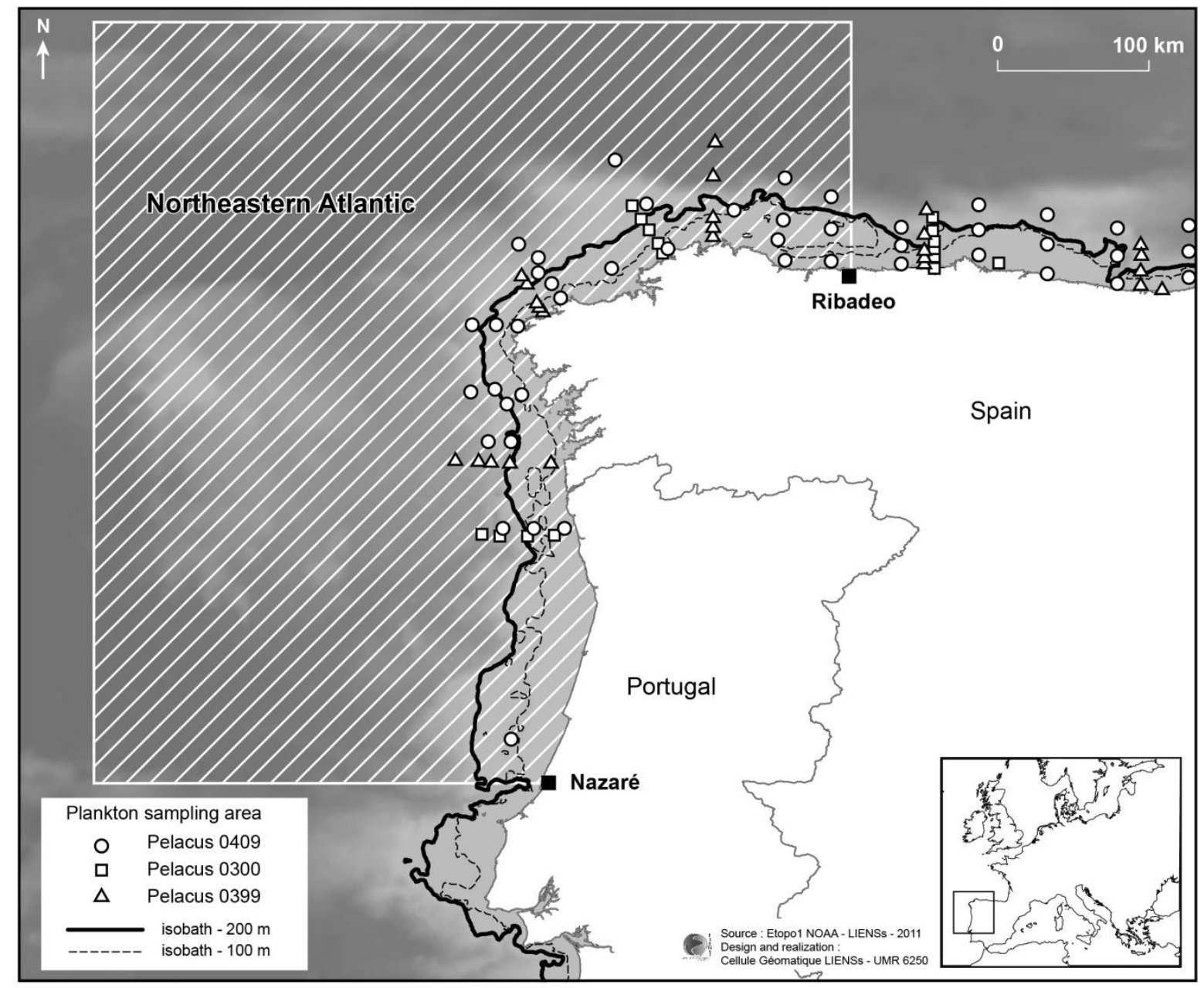

Figure 1. Map of the NWIP with location of plankton stations and with 100 and $200 \mathrm{~m}$ isobaths. The $200 \mathrm{~m}$ isobath was taken as the limit for the shelf-break.

Plankton samples were subsequently fractionated through a $200 \mu \mathrm{m}$ mesh, carefully washed with filtered seawater, transferred to glass-fiber filters and stored frozen until subsequent isotopic analysis (Bode et al. 2007). Only nitrogen isotopes were analyzed for the PELACUS0409 samples. Carbon isotopes were also measured in samples collected during the PELACUS0399 (March 1999) and PELACUS0300 (March 2000) surveys in the same area (Bode et al. 2003). Samples from these surveys were collected as described for the nitrogen isotope samples but using a net of $20 \mu \mathrm{m}$ mesh, thus comprising plankton in the $20-200 \mu \mathrm{m}$ size range. The isotopic composition of this fraction is expected to be essentially the same as that of the 40-200 $\mu \mathrm{m}$ sample from 2009 , as there is no significant isotopic enrichment within 
plankton fractions $<200 \mu \mathrm{m}$ (see Bode et al. 2007). All isotopic values from plankton in the region were pooled to obtain representative estimates of isotopic composition taking into account spatial and temporal variability (Bode et al. 2004, 2007). Specimens of common octopus (Octopus vulgaris), curled octopus (Eledone cirrhosa) and cuttlefish (Sepia officinalis) were acquired in the Vigo (Galicia) fish market, while oceanic cephalopod species with no commercial value (the squids Teuthowenia megalops, sharpear enope Ancistrocheirus lesueurii, armed cranch Galiteuthis armata, umbrella Histioteuthis bonnellii and elongate jewel squid $H$. reversa) were collected during the EVHOE groundfish surveys conducted by the Institut Français de Recherche pour l'Exploitation de la Mer (IFREMER), from the southern part of the Bay of Biscay in autumn, 2001 to 2008.

Table 1. Number of individuals of the toothed whale species stranded or by-caught per year in the study area: common dolphin Delphinus delphis (Dde), harbour porpoise Phocoena phocoena (Pph), bottlenose dolphin Tursiops truncatus (Ttr), striped dolphin Stenella coeruleoalba (Sco) and longfinned pilot whale Globicephala melas (Gme).

\begin{tabular}{ccccccc}
\hline Year & All & Dde & Pph & Ttr & Scc & Gme \\
\hline 2004 & 16 & 4 & 5 & 1 & 2 & 4 \\
2005 & 29 & 21 & 2 & 2 & 4 & 0 \\
2006 & 24 & 14 & 3 & 3 & 3 & 1 \\
2007 & 60 & 42 & 5 & 2 & 9 & 2 \\
2008 & 43 & 33 & 4 & 1 & 3 & 2 \\
\hline Total & 172 & 114 & 19 & 9 & 21 & 9 \\
\hline
\end{tabular}

Individuals of each species were measured, weighted and dissected to obtain portions of lateral white muscle or mantle (for fish and cephalopods, respectively), which were also stored at $-20{ }^{\circ} \mathrm{C}$ prior to analysis. 


\section{Stable isotope analysis}

Muscle and mantle samples were freeze-dried and then ground into a fine powder. Since lipids are highly depleted in ${ }^{13} \mathrm{C}$ relative to other tissue components (DeNiro \& Epstein 1978), they were extracted from these samples using cyclohexane. To this end, an aliquot of approximately $100 \mathrm{mg}$ of fine powder was agitated with $4 \mathrm{~mL}$ of cyclohexane for $1 \mathrm{~h}$. Next, the sample was centrifuged for $5 \mathrm{~min}$ at $4000 \mathrm{~g}$, and the supernatant containing lipids was discarded. The sample was dried in an oven at $45{ }^{\circ} \mathrm{C}$ for $48 \mathrm{~h}$, and $0.35 \pm 0.05 \mathrm{mg}$ subsamples of lipid-free powder were then weighed in tin cups for stable isotope analyses. Plankton samples were analyzed after oven drying at $50{ }^{\circ} \mathrm{C}$ for $24 \mathrm{~h}$ with no lipid extraction.

These analyses were performed with an elemental analyzer coupled to an Isoprime (Micromass) continuous-flow isotope-ratio mass spectrometer (CF IR-MS). Plankton samples were analyzed using an isotope-ratio mass spectrometer (Finnigan Matt Delta Plus) coupled to an elemental analyzer (Carlo Erba CHNSO 1108).

The results are presented in the usual $\delta$ notation relative to Vienna PeeDee Belemnite Standard for $\delta^{13} \mathrm{C}$ and atmospheric $\mathrm{N}_{2}$ for $\delta^{15} \mathrm{~N}$, in parts per thousand (\%). Replicate measurements of internal laboratory standards (acetanilide) during each autorun indicate measurements errors $<0.2 \%$ for $\delta^{13} \mathrm{C}$ and $\delta^{15} \mathrm{~N}$.

\section{Isotopic model}

The trophic position (TP) of toothed whale and prey species was estimated from $\delta^{15} \mathrm{~N}$ following Vander Zanden \& Rasmussen (2001):

$$
\mathrm{TP}=2+\left(\delta^{15} \mathrm{~N}_{\text {consumer }}-\delta^{15} \mathrm{~N}_{\text {base }}\right) / \mathrm{TEF}
$$

where $\delta^{15} \mathrm{Nconsumer}$ is the mean $\delta^{15} \mathrm{~N}$ value of a given consumer (toothed whale, fish or cephalopod species in this case). The $\delta^{15} \mathrm{~N}$ value of $<200 \mu \mathrm{m}$ fraction of plankton was attributed to primary consumers $\left(\delta^{15} \mathrm{~N}_{\text {base }}\right)$ and thus represented the reference value at the base of the food web ( $\mathrm{TP}=2$; Bode et al. 2007). In their study, Vander Zanden \& Rasmussen 
(2001) used a mean TEF of 3.4\%o which is a valid approximation of trophic fractionation only when averaged over multiple trophic pathways (Post 2002). However, there is increased evidence that the TEF can vary widely depending on the taxon of the consumer or depending on the type and quality of its food. To our knowledge, only two published experimental studies have determined the TEF in marine mammals. Hobson et al. (1996) fed two harp seals (Pagophilus groenlandicus) on a constant diet of herring (Clupea harengus) and obtained a TEF value of $2.4 \%$ for $\delta^{15} \mathrm{~N}$ in muscle tissue. The second study was carried out on three captive bottlenose dolphins and five killer whales (Orcinus orca) (Caut et al. 2011). A TEF value of $1.2 \%$ for $\delta^{15} \mathrm{~N}$ in muscle tissue was calculated for killer whales but was based on the results of a single individual that died during the experiment due to a bacterial infection. Thus we used a TEF appropriate to each major type of consumer analyzed and derived from the literature, $2.4 \%$ to calculate TP for marine mammals and 3.4\%o to calculate the prey TP.

\section{Data analysis}

Mean isotopic composition in muscle, and its standard deviation (SD) and 95\% confidence intervals, were calculated for toothed whales, their prey and plankton. The existence of significance differences in the isotopic composition of the samples was investigated using ANOVA or Kruskal-Wallis tests among species, separately for both $\delta^{13} \mathrm{C}$ and $\delta^{15} \mathrm{~N}$ values. The choice of test was based on the results of Shapiro (to check for normality in the sample distributions) and Bartlett (to check the homogeneity of variances) tests.

Isotopic mixing models were applied with the software package SIAR (Stable Isotope Analysis in R) to estimate the proportional contribution of sources (dietary items) within the isotopic mixture (consumer tissue) of the common dolphin. The main prey species contributing to their total diet by weight determined from stomach content analyses (Santos et al. 2004a,c) were considered as sources: blue whiting, sardine, scad, sand smelt, mackerel (Scomber scombrus), pouting, common squid and hake. For sand smelt, isotopic values from 
the literature were used (Fernández et al. 2011a) since we did not sample this species. The isotopic values for food sources must be adjusted by appropriate enrichment factors between diet and consumer tissue (Phillips \& Gregg 2003) and therefore the use of surrogate or proxy discrimination factors may not be appropriate for species or tissues for which the specific TEF are unknown (Bond \& Diamond 2011). Obtaining this information is particularly challenging for marine mammals and birds because individuals must be held on an isotopically fixed diet in controlled conditions that allow for regular sampling over lengthy periods of time. We have used the two range values available in the literature (see above). Two model runs were carried out: (1) using $1.3 \% \mathrm{~m} \pm 0.1$ for $\delta^{13} \mathrm{C}$ and $2.4 \% \mathrm{~m} \pm 0.3$ for $\delta^{15} \mathrm{~N}$ (Hobson et al. 1996) and (2) using $0.3 \%_{0} \pm 0.2$ for $\delta^{13} \mathrm{C}$ and $1.2 \%$ \pm 0.1 for $\delta^{15} \mathrm{~N}$ (Caut et al. 2011). Finally we ran the mixing models using default parameters (iterations $=500,000$, burnin $=50,000$, thinby $=15$ ).

All models and statistical tests mentioned above were performed using the free software R, version 2.11.1 (R Development Core Team 2010).

\section{RESULTS}

\section{Stable isotope composition of prey and plankton}

Values of $\delta^{13} \mathrm{C}$ and $\delta^{15} \mathrm{~N}$ differed significantly between prey species and plankton $(H=105.03$ and 86.4 respectively, $P<0.0001)$. As expected, plankton showed the lowest $\delta^{13} \mathrm{C}$ values $(-$ 19.6\%o). There was wide variation in the $\delta^{13} \mathrm{C}$ values of the different prey organisms collected from the NWIP. Plankton, fish and cephalopods exhibited $\delta^{13} \mathrm{C}$ values (Table 2), ranging from $-19.6 \%$ for the sharpear enope squid to $-15.3 \%$ for pouting, a trend broadly consistent with an increase from the offshore system to the inshore system. Three broad groups can be identified (Figure 2), consisting of oceanic squids (Teuthowenia megalops, sharpear enope, armed cranch, umbrella and elongate jewel squid) and oceanic fish (silvery lightfish) in one group, pelagic fish (sardine, mackerel, scad), hake, blue whiting and common squid in a second 
group, and a third group including coastal/benthic cephalopods and fish (common octopus, cuttlefish, curled octopus and pouting).

Regarding $\delta^{15} \mathrm{~N}$ values, as for $\delta^{13} \mathrm{C}$, pouting exhibited the highest values (14.0\%) while the lowest mean $\delta^{15} \mathrm{~N}$ values were recorded in the oceanic squids Teuthowenia megalops and armed cranch squid (9.0\% and $9.7 \%$, respectively), followed by sardine and the silvery lightfish (both 10.2\%). Plankton (as was the case for $\delta^{13} \mathrm{C}$ ) exhibited the lowest $\delta^{15} \mathrm{~N}$ values (5.2\%o) (see Table 2).

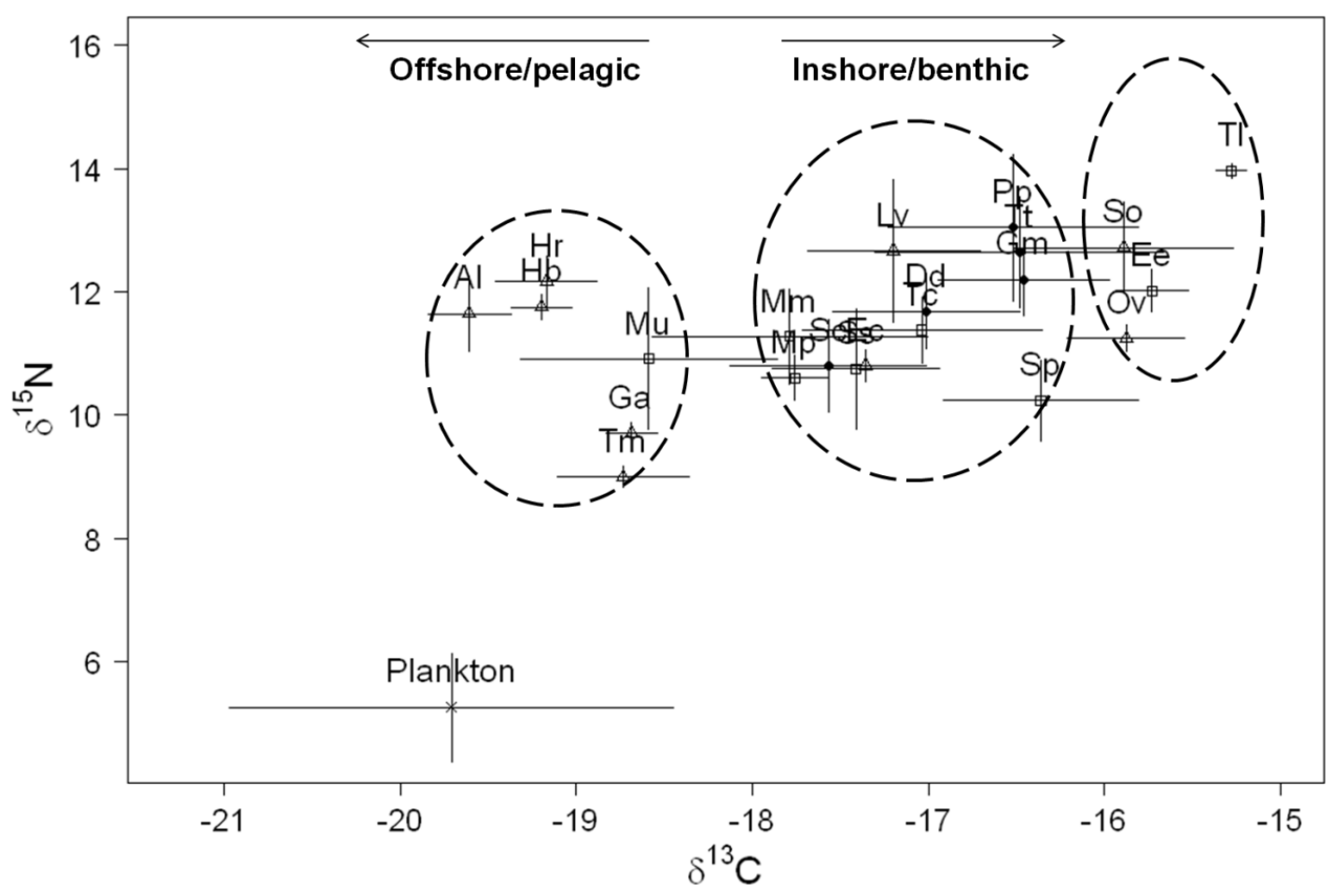

Figure 2. Carbon $\left(\delta^{13} \mathrm{C}\right)$ and nitrogen $\left(\delta^{15} \mathrm{~N}\right)$ isotope ratios (mean $\pm \mathrm{SD}$ and ranges, \%o) in plankton and in the muscle tissue of selected fish, cephalopods, and toothed whale species of the NWIP. The discontinuous ellipses grouped the species according to their distribution on the offshore-inshore axis and $\delta^{13} \mathrm{C}$ values: sharpear enope squid Ancistrocheirus lesueurii ( $\mathrm{Al}$ ), common dolphin Delphinus delphis (Dd), Curled octopus Eledone cirrhosa (Ee), armed cranch squid Galiteuthis armata (Ga), long-finned pilot whale Globicephala melas (Gm), umbrella squid Histioteuthis bonnellii $(\mathrm{Hb})$, elongate jewel squid $H$. reversa $(\mathrm{Hr})$, common squid Loligo vulgaris (Lv), silvery lightfish Maurolicus muelleri (Mu), hake Merluccius merluccius (Mm), blue whiting Micromesistius poutassou (Mp), common octopus Octopus vulgaris (Ov), harbour porpoise Phocoena phocoena (Pp), sardine Sardina pilchardus (Sp), mackerel Scomber scombrus (Ss), cuttlefish Sepia officinalis (So), striped dolphin Stenella coeruleoalba (Sc), Teuthowenia megalops (Tm), scad Trachurus trachurus (Tc), pouting Trisopterus luscus (Tl) and bottlenose dolphin Tursiops truncatus (Tt). 


\section{Stable isotope composition and trophic position of toothed whales}

The muscle $\delta^{13} \mathrm{C}$ and $\delta^{15} \mathrm{~N}$ values of the five toothed whales differed significantly between species (Kruskal-Wallis, $H=30.39$ and 60.26, respectively, both $P<0.0001$; Table 3). As revealed by the mean $\delta^{13} \mathrm{C}$ values (Post-hoc test, $\left.P<0.05\right)$ three major groups exist as delineated by their distribution along the coastal-oceanic axis (Figure 3). The first group was characterized by the highest $\delta^{13} \mathrm{C}$ values (-16.5\%) and included harbour porpoise, bottlenose dolphin and long-finned pilot whale. The most depleted and highly negative mean $\delta^{13} \mathrm{C}$ value $(-17.6 \%)$ was found in the muscle of striped dolphin whereas common dolphin exhibited a value for $\delta^{13} \mathrm{C}(-17.0 \%)$ which was intermediate between these two groups.

Comparison tests showed that $\delta^{15} \mathrm{~N}$ values in muscle of striped dolphin were significantly lower than those of the other species (Post-hoc tests, all $P<0.05$ ), and $\delta^{15} \mathrm{~N}$ values in muscle of harbour porpoise were significantly higher than those in the other species with the exception of bottlenose dolphin. The $\delta^{15} \mathrm{~N}$ value of bottlenose dolphin was higher than those of common dolphin $(P<0.01)$ and long-finned pilot whale but not statistically different from the latter. Finally, $\delta^{15} \mathrm{~N}$ values were not statistically different between long-finned pilot whales and common dolphins (Table 3 \& Figure 3).

Trophic positions (TP) of toothed whale species were estimated based on the $\delta^{15} \mathrm{~N}$ values of prey and primary consumers (Figure 4), and showed no significant differences among the five species (ANOVA, $P>0.05$; Table 3 ). 


\section{Trophic relationship between predators and prey}

The five toothed whales had higher $\delta^{15} \mathrm{~N}$ values in muscle than those obtained from the prey species, with the exception of striped dolphins which showed nitrogen stable isotope values lower than pouting. Comparing the isotopic values between diet (i.e. the main prey selected from literature for each predator species) and muscle (tissue) of the five toothed whales mean TEF values of $1.4 \%$ for $\delta^{15} \mathrm{~N}$ and $0.8 \%$ for $\delta^{13} \mathrm{C}$ were obtained. Note that these are unweighted means which do not take into account the relative importance of the different species and included only those prey species that could be sampled.

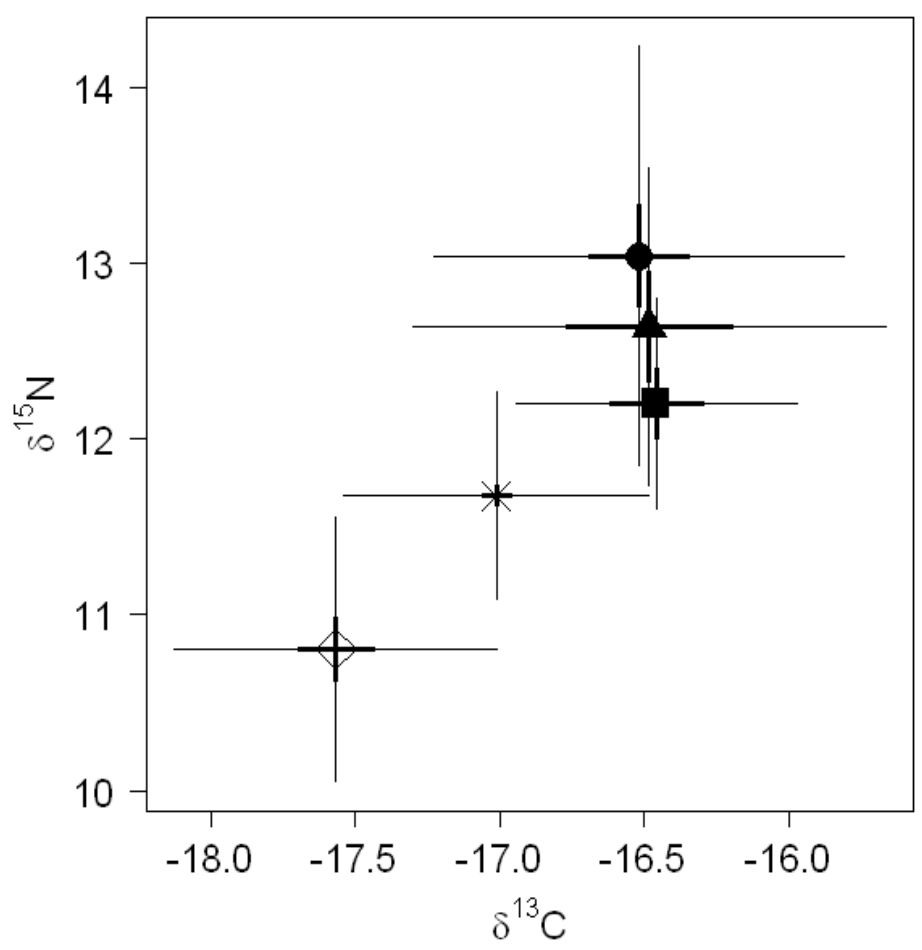

Figure 2. Carbon $\left(\delta^{13} \mathrm{C}\right)$ and nitrogen $\left(\delta^{15} \mathrm{~N}\right)$ isotope ratios in muscle tissue of striped dolphin Stenella coeruleoalba $(\diamond)$, common dolphin Delphinus delphis $(\times)$, long-finned pilot whale Globicephala melas (ם), bottlenose dolphin Tursiops truncatus ( $\mathbf{\Delta})$ and harbour porpoise Phocoena phocoena $(\bullet)$ from the NWIP. Data are mean $(\%) \pm$ SD and standard error (bold). 
Results from the isotopic mixing model (SIAR) for common dolphin suggest a high contribution of blue whiting to the diet of this species based on muscle isotopic values. When we used the TEF from Hobson et al. (1996) (model 1, see Figure 5a), blue whiting showed a high mean contribution of $91 \%$, with hake in second position but with a much lower mean contribution of $3.5 \%$, followed by mackerel with a mean contribution of $2.9 \%$.

In contrast, when we used the lower TEF suggested by Caut et al. (2011) (model 2, see Figure $5 b)$, results indicated a higher diversity of the diet with a lower contribution of blue whiting than in model1 $(50.8 \%)$ and sardine as the second most important prey species with a mean contribution of $25.5 \%$. Mackerel and hake also exhibited a higher contribution than in model1 with $14.4 \%$ and $4.5 \%$, respectively.

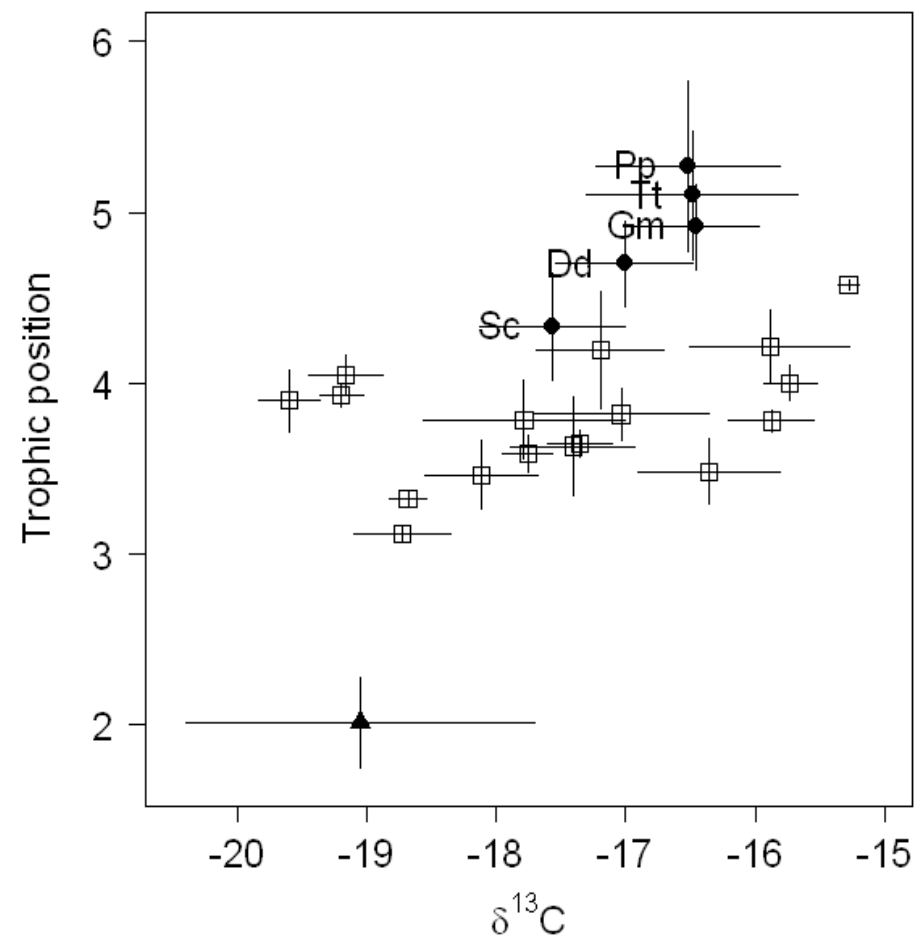

Figure 3. Trophic structure of the NWIP food web as determined by trophic position (TP) and carbon $\left(\delta^{13} \mathrm{C}\right)$ isotope ratios of their different components: Striped dolphin Stenella coeruleoalba (Sc), common dolphin Delphinus delphis (Dd), long-finned pilot whale Globicephala melas (Gm), bottlenose dolphin Tursiops truncatus (Tt), harbour porpoise Phocoena phocoena (Pp), prey species $(\square)$ and plankton $(\boldsymbol{\Delta})$. Data are mean \pm SD. 


\section{DISCUSSION}

\section{Spatial feeding ecology differences in the NWIP food web}

$\delta^{13} \mathrm{C}$ values are generally used as an indicator of the habitat and/or feeding zone of an organism (France 1995). Here $\delta^{13} \mathrm{C}$ values varied from $-21.0 \%$ to $-15.1 \%$ with plankton being ${ }^{13} \mathrm{C}$-depleted relative to fish, cephalopods and toothed whale species, as would be expected from its position at the base of the consumer chain. $\delta^{13} \mathrm{C}$ isotopic values showed a decreasing trend from coastal and neritic habitats to oceanic and deep-sea habitats (Figures 2 \& 3). This offshore-inshore gradient has been previously described in freshwater and marine ecosystems (Fry \& Sherr 1984, Hobson 1999, Sherwood \& Rose 2005). Fish and cephalopod species, which were more 13C-enriched compared to marine plankton, showed considerable segregation between species along this oceanic-coastal axis (Figure 2). Sharpear enope squid, umbrella squid, elongate jewel squid, Teuthowenia megalops, armed cranch squid and silvery lightfish have the most ${ }^{13} \mathrm{C}$-depleted values due to their oceanic feeding habitat. Common octopus, common cuttlefish, anchovy and pouting showed the highest $\delta^{13} \mathrm{C}$ values, consistent with their more coastal and/or benthic habitats. In the case of hake, blue whiting, mackerel, scads, common squid and sardine, the $\delta^{13} \mathrm{C}$ values are intermediate between the previously mentioned prey species (Figure 2). Similar results were obtained by Fernández et al. (2011a) who analyzed stable isotope signatures of 17 prey species of bottlenose dolphins in Galicia waters. Regarding the community of toothed whales inhabiting NWIP waters, we found interspecific differences in their $\delta^{13} \mathrm{C}$ values. These values ranged from -18.5 for striped dolphin to $-15.1 \%$ for harbour porpoise and bottlenose dolphin and suggest that the species analyzed are spatially segregated and/or specialize on different prey in the study area. Thus structuring is present even though the continental shelf area is relatively limited, due to the narrowness of the continental shelf $\left(<40 \mathrm{~km}\right.$ wide). The ${ }^{13} \mathrm{C}$-depletion observed in striped dolphin and common dolphin relative to the other three toothed whale species (Figure 3) may 
result from an exploitation of oceanic, relatively ${ }^{13} \mathrm{C}$-depleted, resources by both species. Striped dolphin shows a high level of foraging plasticity, as evidenced by several studies carried out in various part of the world (Miyazaki et al. 1973, Desportes 1985, Meotti \& Podestà 1997, Ringelstein et al. 2006, Spitz et al. 2006). In the NWIP, the main fish prey of striped dolphin are blue whiting, scads and sand smelt while the main cephalopods eaten are Gonatus sp. and ommastrephids (Santos et al. 2007b). It is also known that striped dolphins in the NWIP feed on crustaceans, specifically on pelagic shrimp species (Jose Cedeira Personal communication), and on oceanic fish such as silvery lightfish. Thus, although some coastal species have been found in the stomach contents of NWIP striped dolphins, the low $\delta^{13} \mathrm{C}$ values of the present study tend to show that this dolphin species mainly exploits the oceanic habitats of the NWIP.

Common dolphin is the most abundant cetacean in the NWIP (López et al. 2004) and the second most frequently sighted from the coast (Pierce et al. 2010). Observations from fishing boats suggest that this species is mainly found in waters of less than $200 \mathrm{~m}$ depth (Spyrakos et al. 2011). This apparent preferential use of shallow waters may relate to foraging preferences. The most important prey of common dolphin in Galician waters are blue whiting and sardine as shown by the analysis of stomach contents of stranded and by-caught individuals (Santos et al. 2004c) and here supported by the isotopic mixing models results, which suggested that blue whiting is the most important prey and that, depending on assumptions made about trophic fractionation, sardine may be the second most important prey (see Figure 5). It is clear from comparing the results of the two mixing models that the details of the results are strongly dependent on the trophic fractionation assumed and caution is thus needed in interpreting such models (see below for further discussion on this point). Common dolphin probably feeds on blue whiting on the upper part of the shelf break, while sardine is taken on the shelf and in more coastal areas. This would explain the intermediate ${ }^{13} \mathrm{C}$ value of the 
common dolphin, i.e. between that of the striped dolphin and those of the other toothed whales found in our study. This result is in agreement with the results of similar work carried out in the same area and in other areas of the North East Atlantic: Ireland (Das et al. 2003a), the French Channel (Das et al. 2003a) and the Bay of Biscay (Chouvelon et al. in press) (see Table 4).

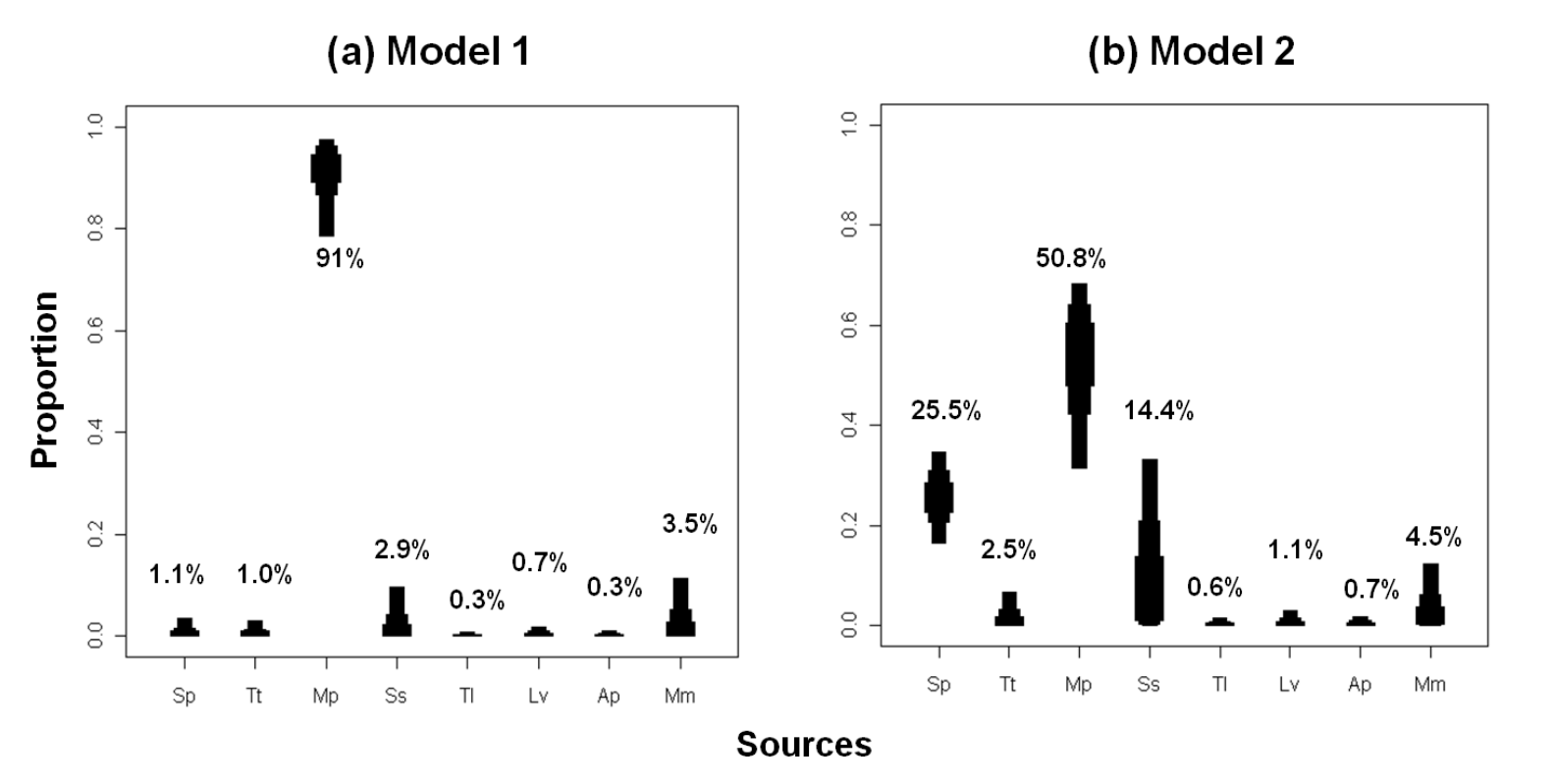

Figure 4. Results of SIAR mixing model (50\%, $75 \%$ and $95 \%$ confidence intervals) showing the probable sources proportion in diet of Delphinus delphis in the NWIP. Model 1 (a) was run with a TEF of $1.3 \pm 0.1$ and $2.4 \pm 0.3$ for $\delta^{13} \mathrm{C}$ and $\delta^{15} \mathrm{~N}$, respectively, and model 2 (b) was run with a TEF of $0.34 \pm 0.2$ and $1.21 \pm 0.15$ for $\delta^{13} \mathrm{C}$ and $\delta^{15} \mathrm{~N}$, respectively (Caut et al. 2011, Hobson et al. 1996). The mean proportion (\%) of each source is labeled: sardine Sardina pilchardus (Sp), scad Trachurus trachurus (Tt), blue whiting Micromesistius poutassou (Mp), mackerel Scomber scombrus (Ss), pouting Trisopterus luscus (T1), common squid Loligo vulgaris (Lv), sand smelt Atherina presbyter (Ap) and hake Merluccius merluccius (Mm).

While $\delta^{13} \mathrm{C}$ isotopic values were not significantly different between harbour porpoise, bottlenose dolphin and long-finned pilot whale, these species exhibited ${ }^{13} \mathrm{C}$-enriched values when compared to common and striped dolphins (Figure 3). This could be related to a more coastal distribution of these three species or a greater use of benthic resources. Harbour porpoises tend to be seen where the shelf is narrower and where the average water depth is 90 
$\mathrm{m}$ (Pierce et al. 2010). In this study, the harbour porpoise exhibited a mean $\delta^{13} \mathrm{C}$ value of $16.5 \%$ while its main prey in Galician waters, scads and pouting (Santos et al. 2004a, Pierce et al. 2010) exhibited mean $\delta^{13} \mathrm{C}$ values of $-15.3 \%$ and $-17.0 \%$, respectively. These values are consistent with the coastal distribution of both predator and prey and can explain the high $\delta^{13} \mathrm{C}$ values obtained for harbour porpoise. These estimates are also very close to the values found for the same species in studies carried out in French Channel coastal waters $(-16.1 \%$; Das et al. 2003a), the Irish coast (-16.5\%; Das et al. 2003a) and North Sea (-16.4\%; Das et al. 2003c) (see Table 4).

In the NWIP bottlenose dolphin is the species most frequently sighted from the coast (Pierce et al. 2010) but there are also sightings of this species in offshore waters (e.g. López et al. 2004). Two recent studies demonstrated the existence of ecological and genetic differences between the animals stranded in the southern part of the Galician Rías (originating from the proposed resident population in these coastal waters) and those stranded elsewhere (Fernández et al. 2011a,b). The high variability obtained in the $\delta^{13} \mathrm{C}$ values of bottlenose dolphin in the present study could be explained by the presence in our samples of individuals from both the inshore and offshore populations, which would exploit different prey species. Santos et al. (2007a) found blue whiting and hake to be the most important prey species of stranded and by-caught bottlenose dolphins in Galicia, both numerically and in terms of biomass. Both blue whiting and hake exhibited consistent $\delta^{13} \mathrm{C}$ isotopic values, approximately 1\%o lower than bottlenose dolphins, harbour porpoises and long-finned pilot whales (Tables 2 \& 3) although the latter toothed whale species is mainly teuthophagous (Pierce et al. 2007). The ${ }^{13} \mathrm{C}$-enrichment (-16.5\%) measured in long-finned pilot whale tissues suggests a coastal habitat or that the individuals were mainly foraging on more coastal and/or benthic species over the sampling period (2004-2008). Although pilot whales are considered an oceanic species (Mead \& Brownell 2005), foraging over the shelf is believed to take place since 
coastal cephalopod species such as common and curled octopus have been recorded in the stomach (González et al. 1994; Santos unpublished data) and are sometimes sighted from the coast (Pierce et al. 2010). Similar results were obtained by Spitz et al. (2011) in the northern Bay of Biscay, who reported the diet of this species as being a unique combination of mesopelagic prey living in oceanic waters and of prey living at or close to the bottom in neritic waters.

\section{Pattern of nitrogen isotope ratios and trophic relationships}

The primary utility of nitrogen isotope ratios for animal ecology lies on their relationship with trophic level (e.g. Hobson 1999). Previous studies have indicated that pelagic foodwebs in upwelling areas are relatively short due to the prevalence of the plankton consumers (Ryther 1969) but in our case, the food web exhibited five trophic levels, with the toothed whales occupying the highest level, which is relatively long for an upwelling system. In the NWIP the TPs varied little among most fishes and cephalopods. However, a ${ }^{15} \mathrm{~N}$-enrichment occurs along the oceanic (and/or pelagic) - coastal (and/or benthic) axis, the most coastal and benthic species exhibiting the highest TP (pouting, common squid and cuttlefish as an example). Toothed whales occupy the top positions of the food web with a narrow range of TP (4.3 to 5.3), with no significant between-species differences being found in their TPs. However, an overlap in TP does not necessarily imply an overlap in diet, since animals may feed on different prey species with similar TPs.

In the present study the TEF measured in muscle of the five toothed whales with respect to muscle of their main prey was found to be $0.8 \%$ for $\delta^{13} \mathrm{C}$ and $1.4 \%$ for $\delta^{15} \mathrm{~N}$. These results are much lower than those obtained by previous studies but agree quite well with the results of Caut et al. (2011) who obtained TEF values from the muscle of a single captive killer whale fed on controlled diets $\left(0.3 \%\right.$ for $\delta^{13} \mathrm{C}$ and $1.2 \%$ for $\left.\delta^{15} \mathrm{~N}\right)$. Moreover several sources of variation, including the analytical methodology and dietary differences, have been proven 
to affect $\delta^{13} \mathrm{C}$ and $\delta^{15} \mathrm{~N}$ enrichment factors (e.g. Vanderklift \& Ponsard 2003). In the present study, TEF should be interpreted with caution as they were estimated based on rather few samples and only the main prey (as identified from stomach content analyses) were selected for the TEF calculations. However, due to the fact that isotope models are very sensitive to changes of TEF (Ben-David \& Schell 2001, Bond \& Diamond 2011), the use of dietdependent TEF could significantly change the results and hence the interpretation. As an example, in our mixing models, applying a lower TEF significantly changed the contribution of the main prey of common dolphin (blue whiting) from 91 to 50.8\% (see Figure 5). Mixing models suggest a high consumption of blue whiting by common dolphins, which is in agreement with diet studies based on stomach contents (Santos et al. 2004c) and this high proportion of blue whiting would explain the low $\delta^{15} \mathrm{~N}$ values found in NWIP common dolphins.

It was not possible to investigate the extent of the temporal and/or spatial overlap in the trophic signatures between species in this study, since stable isotope values were analyzed in individuals stranded in different seasons over a period of four years over a wide area. Our sample size was insufficient to allow the investigation of these differences. Furthermore, there is also considerable variability in the isotopic composition of plankton and their consumers from year to year (Bode et al. 2007). For these reasons we used pooled values for plankton isotopic composition from several surveys to better characterize the isotopic baseline, instead of average values obtained from a single survey. 


\section{Conclusion}

Despite the frequent sightings of striped dolphin and common dolphin over the continental shelf of the NWIP, their $\delta^{13} \mathrm{C}$ and $\delta^{15} \mathrm{~N}$ values in muscle seem to indicate that they mainly feed in offshore waters although they probably target different prey species. Harbour porpoise, bottlenose dolphin and long-finned pilot whale appear to frequent the coastal (or inshore) habitats and to feed on higher trophic level prey than either striped or common dolphin. However, dietary segregation probably also occurs between these three more coastal species (the first two are mainly piscivorous but may take different sizes of prey while longfinned pilot whales feed mainly on cephalopods). The low TEF estimated in this study allows a food web with five trophic levels where the toothed whales studied occupy the top positions. In addition, the SIAR analyses confirmed that common dolphin seem to feed mostly on important economical species such as blue whiting, sardine and mackerel in our study area (as shown by previous studies on stomach contents analyses). This is also probably the case for the other four toothed whale species and highlights the need to take this information into account when designing and implementing conservation measures such as Special Areas of Conservation (SACs). By exploiting the same resources as the fisheries, toothed whales in the NWIP could be at risk from both prey depletion and incidental capture in fishing gear (bycatch) and, indeed there is abundant evidence that by-catch of cetaceans is a common occurrence (López et al. 2002, 2003, Fernández-Contreras et al. 2010). Interaction with fisheries and any other anthropogenic activity are a particular cause for concern in relation to the conservation of the recently described isolated Iberian harbour porpoise population and the resident bottlenose dolphin population inhabiting the southern Galician Rías. Our work highlights the usefulness of stable carbon and nitrogen isotope ratios together with mixing models (albeit with some caveats concerning the latter) to gain understanding on the trophic relationships and the structure of marine food webs. Because the information on diet provided 
by the isotopic analysis is relatively coarse but potentially covers a long time-scale, while stomach contents analysis provides snapshots of detailed diet composition, the ideal approach involves a combination of these techniques. In combination, and together with the analysis of other ecological tracers, these methods will allow information on feeding ecology to be obtained over a range of different time spans. 
Table 2. Carbon $\left(\delta^{13} \mathrm{C}\right)$ and nitrogen $\left(\delta^{15} \mathrm{~N}\right)$ isotope ratios (mean $\left.\pm \mathrm{SD}, \%\right)$, length range $(\mathrm{cm})$ and mean trophic position of sampled fish, cephalopods and plankton from the NWIP. Lengths are total length for fish and dorsal mantle length for cephalopods. TP: trophic position.

\begin{tabular}{|c|c|c|c|c|c|}
\hline \multirow{2}{*}{ Species } & \multirow{2}{*}{$\mathrm{n}$} & Length range & $\delta^{13} \mathrm{C}(\%)$ & $\delta^{15} \mathrm{~N}(\%)$ & \multirow{2}{*}{$\mathrm{TP}$} \\
\hline & & $(\mathrm{cm})$ & mean $\pm \mathrm{SD}$ & mean $\pm \mathrm{SD}$ & \\
\hline \multicolumn{6}{|l|}{ Fish } \\
\hline Sardine (Sardina pilchardus) & 15 & $18.5-22.5$ & $-16.4 \pm 0.5$ & $10.2 \pm 0.6$ & 3.5 \\
\hline Anchovy (Engraulis encrasicolus) & 5 & $15.5-17.0$ & $-15.7 \pm 0.2$ & $12.0 \pm 0.3$ & 4.0 \\
\hline Blue whiting (Micromesistius poutassou) & 10 & $22.0-24.0$ & $-17.8 \pm 0.2$ & $10.6 \pm 0.4$ & 3.6 \\
\hline Pouting (Trisopterus luscus) & 3 & $20.0-21.0$ & $-15.3 \pm 0.1$ & $14.0 \pm 0.1$ & 4.6 \\
\hline Hake (Merluccius merluccius) & 8 & $25.5-33.0$ & $-17.8 \pm 0.8$ & $11.3 \pm 0.8$ & 3.8 \\
\hline Scad (Trachurus trachurus) & 19 & $12.0-31.0$ & $-17.0 \pm 0.7$ & $11.4 \pm 0.5$ & 3.8 \\
\hline Mackerel (Scomber scombrus) & 14 & $28.0-32.0$ & $-17.4 \pm 0.5$ & $10.7 \pm 1.0$ & 3.6 \\
\hline Silvery lightfish (Maurolicus muelleri) & 5 & $4.4-5.5$ & $-18.1 \pm 0.4$ & $10.2 \pm 0.7$ & 3.5 \\
\hline \multicolumn{6}{|l|}{ Cephalopods } \\
\hline Curled octopus (Eledone cirrhosa) & 9 & $208.0-495.0$ & $-17.3 \pm 0.2$ & $10.8 \pm 0.2$ & 3.6 \\
\hline Common octopus (Octopus vulgaris) & 5 & $670.0-810.0$ & $-15.9 \pm 0.3$ & $11.2 \pm 0.2$ & 3.8 \\
\hline Cuttlefish (Sepia officinalis) & 5 & $150.0-194.0$ & $-15.9 \pm 0.6$ & $12.7 \pm 0.7$ & 4.2 \\
\hline Common squid (Loligo vulgaris) & 7 & $9.7-27.4$ & $-17.2 \pm 0.5$ & $12.7 \pm 1.2$ & 4.2 \\
\hline
\end{tabular}


Teuthowenia megalops

Armed cranch squid (Galiteuthis armata)

Sharpear enope squid (Ancistrocheirus lesueurii)

Umbrella squid (Histioteuthis bonnellii)

Elongate jewel squid (Histioteuthis reversa)
3

2

3

6

4

Plankton

$\begin{array}{rrr}118.0-147.0 & -18.7 \pm 0.4 & 9.0 \pm 0.2 \\ 147.0-308.0 & -18.7 \pm 0.1 & 9.7 \pm 0.2 \\ 21.0-49.0 & -19.6 \pm 0.2 & 11.6 \pm 0.6 \\ 27.0-73.0 & -19.2 \pm 0.2 & 11.7 \pm 0.2 \\ 30.0-69.0 & -19.2 \pm 0.3 & 12.2 \pm 0.4\end{array}$

Plankton

46

$<200(\mu \mathrm{m})$

$-19.06 \pm 1.3$

$5.2 \pm 0.9$

2.0 
Table 3. Carbon $\left(\delta^{13} \mathrm{C}\right)$ and nitrogen $\left(\delta^{15} \mathrm{~N}\right)$ isotope ratios (mean $\pm \mathrm{SD}, \%$ ), ranges (minimum, maximum) and mean trophic position (TP) of the toothed whale species sampled along the NWIP. Groups with the same letter indicate that isotopic signatures or TP are not significantly different (pairwise multiple comparison test (MPC) in the case of Kruskal-Wallis (KW), post hoc Tukey's test in the case of ANOVA), $\mathrm{n}=$ number of samples.

\begin{tabular}{|c|c|c|c|c|c|c|}
\hline & Species & $\mathrm{n}$ & Mean \pm SD & Range (min, max) & Test and characteristics & Groups \\
\hline \multirow{3}{*}{$\delta^{13} \mathrm{C}$} & Harbour porpoise (Phocoena phocoena) & 19 & $-16.5 \pm 0.7$ & $-17.5,-15.1$ & $\chi^{2}=30.4, \mathrm{df}=4$ & $\mathrm{~b}$ \\
\hline & Striped dolphin (Stenella coeruleoalba) & 21 & $-17.6 \pm 0.6$ & $-18.5,-16,4$ & & $\mathrm{c}$ \\
\hline & Long-finned pilot whale (Globicephala melas) & 9 & $-16.5 \pm 0.5$ & $-17.3,-15.7$ & & $\mathrm{~b}$ \\
\hline \multirow{4}{*}{$\delta^{15} \mathrm{~N}$} & Harbour porpoise & 19 & $13.0 \pm 1.2$ & $11.5,17.1$ & $\chi^{2}=60.2, \mathrm{df}=4$ & $\mathrm{~b}$ \\
\hline & Bottlenose dolphin & 9 & $12.6 \pm 0.9$ & $11.3,14.0$ & $\mathrm{P}<0.0001$ & $\mathrm{~b}, \mathrm{e}$ \\
\hline & Striped dolphin & 21 & $10.8 \pm 0.7$ & $9.8,12.4$ & & $\mathrm{c}$ \\
\hline & Long-finned pilot whale & 9 & $12.2 \pm 0.6$ & $11.0,13.3$ & & $\mathrm{~d}, \mathrm{e}$ \\
\hline $\mathrm{TP}$ & Common dolphin & 114 & 4.7 & $3.8,5.3$ & 1-way ANOVA (+ Tukey's test) & a \\
\hline
\end{tabular}


Table 2.4 Carbon $\left(\delta^{13} \mathrm{C}\right)$ and nitrogen $\left(\delta^{15} \mathrm{~N}\right)$ isotope ratios (mean $\pm \mathrm{SD}, \%$ ) in muscle tissue of the five toothed whale species analyzed in the present study. Values obtained for the same species by other authors are also included for comparison.

\begin{tabular}{|c|c|c|c|c|c|}
\hline Species & Geographic area & $\mathrm{n}$ & $\begin{array}{c}\delta^{13} \mathrm{C}(\%) \\
\text { mean } \pm \mathrm{SD}\end{array}$ & $\begin{array}{c}\delta^{15} \mathrm{~N}(\%) \\
\text { mean } \pm \mathrm{SD}\end{array}$ & References \\
\hline Common dolphin & Bay of Biscay & 26 & $-17.4 \pm 0.5$ & $12.1 \pm 0.6$ & Chouvelon et al. in press \\
\hline \multirow[t]{4}{*}{ Delphinus delphis } & Galicia (NW Spain) & 5 & $-17.0 \pm 0.3$ & $13.1 \pm 0.8$ & Bode et al. 2007 \\
\hline & Channel coast (NE Atlantic) & 8 & $-16.5 \pm 0.5$ & $12.1 \pm 0.4$ & Das et al. 2003a \\
\hline & Irish coast (NE Atlantic) & 14 & $-17.1 \pm 0.4$ & $12.2 \pm 1.0$ & Das et al. 2003a \\
\hline & NW Iberian Peninsula & 114 & $-17.0 \pm 0.5$ & $11.7 \pm 0.6$ & This study \\
\hline Harbour porpoise & Bay of Biscay & 10 & $-17.0 \pm 0.4$ & $13.0 \pm 0.7$ & Chouvelon et al. in press \\
\hline \multirow[t]{4}{*}{ Phocoena phocoena } & Channel coast (NE Atlantic) & 4 & $-16.1 \pm 0.6$ & $16.5 \pm 2.4$ & Das et al. 2003a \\
\hline & Irish coast (NE Atlantic) & 7 & $-16.5 \pm 0.7$ & $14.1 \pm 1.6$ & Das et al. 2003a \\
\hline & North Sea & 46 & $-16.4 \pm 1.6$ & $16.2 \pm 1.6$ & Das et al. $2003 \mathrm{c}$ \\
\hline & NW Iberian Peninsula & 19 & $-16.5 \pm 0.7$ & $13.0 \pm 1.2$ & This study \\
\hline Bottlenose dolphin & Bay of Biscay & 7 & $-16.0 \pm 0.7$ & $14.5 \pm 0.8$ & Chouvelon et al. in press \\
\hline \multirow[t]{2}{*}{ Tursiops truncatus } & Galicia (NW Spain) & 37 & $-16.5 \pm 0.8$ & $12.6 \pm 0.9$ & Fernandez et al. 2011a \\
\hline & NW Iberian Peninsula & 9 & $-16.5 \pm 0.8$ & $12.6 \pm 0.9$ & This study \\
\hline Striped dolphin & Bay of Biscay & 11 & $-17.5 \pm 0.3$ & $11.2 \pm 0.9$ & Chouvelon et al. in press \\
\hline \multirow[t]{3}{*}{ Stenella coeruleoalba } & Channel coast (NE Atlantic) & 3 & $-16.7 \pm 0.4$ & $11.0 \pm 1.8$ & Das et al. 2003a \\
\hline & Irish coast (NE Atlantic) & 3 & $-17.5 \pm 0.1$ & $10.8 \pm 0.6$ & Das et al. 2003a \\
\hline & NW Iberian Peninsula & 21 & $-17.6 \pm 0.5$ & $10.8 \pm 0.7$ & This study \\
\hline Long-finned pilot whale & Bay of Biscay & 16 & $-16.3 \pm 0.8$ & $13.2 \pm 1.7$ & Chouvelon et al. in press \\
\hline Globicephala melas & NW Iberian Peninsula & 9 & $-16.4 \pm 0.5$ & $12.2 \pm 0.6$ & This study \\
\hline
\end{tabular}




\section{References}

2 Abend, A.G., Smith, T.D., 1995. Differences in ratios of stable isotopes of nitrogen in long-finned pilot whales (Globicephala melas) in the western and eastern North Atlantic. ICES J. Mar. Sci. 52, 837-841.

5 Ben-David, M., Schell, D.M., 2001. Mixing models in analyses of diet using multiple stable isotopes: a response. Oecologia 127, 180-184.

7 Bode, A., Carrera, P., Lens, S., 2003. The pelagic foodweb in the upwelling ecosystem of Galicia (NW Spain) during spring: natural abundance of stable carbon and nitrogen isotopes. ICES J. Mar. Sci. 60, 11-22.

10 Bode, A., Alvarez-Ossorio, M.T., Carrera, P. and Lorenzo, J., 2004. Reconstruction of 11 trophic pathways between plankton and the North Iberian sardine (Sardina 12 pilchardus) using stable isotopes. Scientia Marina. 68, 165-178.

13 Bode, A., Alvarez-Ossorio, M.T., Cunha, M.E., Garrido, S., Peleteiro, J.B., Porteiro, C., 14 Valdes, L., Varela, M., 2007. Stable nitrogen isotope studies of the pelagic food web on the Atlantic shelf of the Iberian Peninsula. Progr. Oceanogr. 74, 115-131.

16 Bond, A.L., Diamond, A.W., 2011. Recent Bayesian stable-isotope mixing models are highly sensitive to variation in discrimination factors. Ecol. Appl. 21, 1017-1023.

18 Borrell, A., Aguilar, A., Tornero, V., Sequeira, M., Fernandez, G., Alis, S., 2006. Organochlorine compounds and stable isotopes indicate bottlenose dolphin subpopulation structure around the Iberian Peninsula. Environ. Int. 32, 516-523. 
21 Caut, S., Laran, S., Garcia-Hartmann, E., Das, K., 2011. Stable isotopes of captive 22 cetaceans (killer whales and bottlenose dolphins). J. Exp. Biol. 214, 538-545.

23 Chouvelon, T., Spitz, J., Caurant, F., Mèndez-Fernandez, P., Chappuis, A., Laugier, F., 24 Le GoffE., Bustamante, P., in press. Spatio-temporal variations in stable isotopic 25 signatures revisit the use of $\delta^{15} \mathrm{~N}$ in meso-scale studies of marine food webs. The 26 case of an open ecosystem: the Bay of Biscay (North-East Atlantic). Prog. Oceanogr.

28 Das, K., Beans, C., Holsbeek, L., Mauger, G., Berrow, S.D., Rogan, E., Bouquegneau, J.29 M., 2003a. Marine mammals from northeast Atlantic: relationship between their 30 trophic status as determined by $\delta^{13} \mathrm{C}$ and $\delta^{15} \mathrm{~N}$ measurements and their trace metal 31 concentrations. Mar. Environ. Res. 56, 349-365.

32 Das, K., Lepoint, G., Leroy, Y., Bouquegneau, J.-M., 2003b. Marine mammals from the southern North Sea: feeding ecology data from $\delta^{13} \mathrm{C}$ and $\delta^{15} \mathrm{~N}$ measurements. Mar. 34 Ecol. Progr. Ser. 263, 287-298.

35 DeNiro, M.J., Epstein, S., 1978. Influence of diet on the distribution of carbon isotopes in 36 animals. Geochim. Cosmochim. Acta 42, 495-506.

37 DeNiro, M.J., Epstein, S., 1981. Influence of diet on the distribution of nitrogen isotopes 38 in animals. Geochim. Cosmochim. Acta 45, 341-351.

39 Desportes, G., 1985. La nutrition des odontocètes en Atlantique nordest (côtes Françaises 40 - îles Feroë). PhD dissertation, Université de Poitiers, France. 
41 Fernandez, R., Garcia-Tiscar, S., Santos, M.B., López, A., Martinez-Cedeira, J.A.,

42 Newton, J., Pierce, G.J., 2011a. Stable isotope analysis in two sympatric

43 populations of bottlenose dolphins Tursiops truncatus: evidence of resource 44 partitioning? Mar. Biol. 158, 1043-1055.

45 Fernandez, R., Santos, M.B., Pierce, G.J., Llavona, A., López, A., Silva, M.A., Ferreira,

46 M., Carrillo, M., Cermeño, P., Lens, S., Piertney, S.B., 2011b. Fine-scale genetic structure of bottlenose dolphins, Tursiops truncatus, in Atlantic coastal waters of the Iberian Peninsula. Hydrobiologia 670, 111-125.

49 Fernandez-Contreras, M.M., Cardona, L., Lockyer, C.H., Aguilar, A., 2010. Incidental bycatch of short-beaked common dolphins (Delphinus delphis) by pair trawlers

52 Fraga, F., 1981. Upwelling of the Galician coast, Northwest Spain, in: Richards, F. (Eds.), Coastal Upwelling. American Geophysical Union Washington, DC, pp. $176-182$.

France, R.L., 1995. Carbon-13 enrichment in benthic compared to planktonic algae: food web implications. Mar. Ecol. Progr. Ser. 124, 307-312.

57 Fry, B., Sherr, E.B., 1984. $\delta^{13}$ C measurements as indicators of carbon flow in marine and freshwater ecosystems. Contrib. Mar. Sci. 27, 13-47.

59 Gonzàlez, A.F., López, A., Guerra, A., Barreiro, A., 1994. Diets of marine mammals 60 stranded on the northwestern Spanish Atlantic coast with special reference to $61 \quad$ Cephalopoda. Fish. Res. 21, 179-191. 
62 Hobson, K.A., Welch, H.E., 1992. Determination of trophic relationships within a high 63 Arctic marine food web using $\delta^{13} \mathrm{C}$ and $\delta^{15} \mathrm{~N}$ analysis. Mar. Ecol. Progr. Ser. 84, $649-18$

65 Hobson, K.A., Schell, D.M., Renouf, D., Elizabeth, N., 1996. Stable carbon and nitrogen 66 isotopic fractionation between diet and tissues of captive seals: implications for 67 dietary reconstructions involving marine mammals. Can. J. Fish. Aquat. Sci. 53, $68 \quad 528-533$.

69 Hobson K.A., 1999. Tracing origins and migration of wildlife using stable isotopes: a 70 review. Oecologia 120, 314-326.

71 Knoff, A., Hohn, A., Macko, S., 2008. Ontogenetic diet changes in bottlenose dolphins 72 (Tursiops truncatus) reflected through stable isotopes. Mar. Mam. Sci. 24, 128$73 \quad 137$.

74 Kuiken, T., 1996. Review of the criteria for the diagnosis of by-catch in cetaceans, in: 75 Kuiken, T. (Eds.), Diagnosis of by-catch in cetaceans. Proceedings of the Second 76 ECS Workshop on Cetacean Pathology, newsletter 26 (Special Issue), Saskatoon, 77 Saskatchewan, Canada: European Cetacean Society, pp. 38-43.

78 López, A., Santos, M.B., Pierce, G.J., Gonzalez, A.F., Valeiras, X., Guerra, A., 2002. 79 Trends in strandings of cetaceans on the Galician coast, NW Spain, during the 80 1990s. J. Mar. Biol. Assoc. UK 82, 513-521. 
81 López, A., Pierce, G.J., Santos, M.B., Gracia, J., Guerra, A., 2003. Fishery by-catches of

82 marine mammals in Galician waters: results from on-board observations and an 83 interview survey of fishermen. Biol. Conserv. 111, 25-40.

84 López, A., Pierce, G.J., Valeiras, X., Santos, M.B., Guerra, A., 2004. Distribution 85 patterns of small cetaceans in Galician waters. J. Mar. Biol. Assoc. UK 84, $283-$ 86294.

87 Mead, J.G., Brownell Jr., R.L., 2005. Order Cetacea, in: Wilson, D.E., Reeder, D.M. 88 (Eds), Mammal Species of the World: A Taxonomic and Geographic Reference, 89 Johns Hopkins University Press, Baltimore, pp. 723-743.

90 Mendes, S., Newton, J., Reid, R.J., Zuur, A.F., Pierce, G.J., 2007. Stable carbon and 91 nitrogen isotope ratio profiling of sperm whale teeth reveals ontogenetic 92 movements and trophic ecology. Oecologia 151, 605-615.

93 Meotti, C., Podestà, M., 1997. Stomach contents of striped dolphins, Stenella 94 coeruleoalba (Meyen, 1833), from the Western Ligurian, Sea (Cetacea, 95 Delphinidae). Atti della Società Italiana di Scienze Naturali e del Museo Civico di 96 Storia Naturale di Milano 137, 5-15.

97 Miyazaki, N., Kusaka, T., Nishiwaki, M., 1973. Food of Stenella coeruleoalba. Scientific 98 Reports of the Whales Research Institute 25, 265-275.

99 Muir, D.C.G., Segstro, M.D., Hobson, K.A., Ford, C.A., Stewart, R.E.A., Olpinski, S., 100 1995. Can seal eating explain elevated levels of PCBs and organochlorine 
pesticides in walrus blubber from eastern Hudson Bay (Canada)? Environ. Pollut. $96,335-348$.

103 Ostrom, P.H., Lien, J., Macko, S.A., 1993. Evaluation of the diet of Sowerby's beaked 104 whale, Mesoplodon bidens, based on isotopic comparisons among northwestern 105 Atlantic cetaceans. Can. J. Zool. 71, $858-861$.

106 Phillips, D.L., Gregg, J.W., 2003. Source partitioning using stable isotopes: coping with too many sources. Oecologia 136: 261-269.

108 Pierce, G.J., Boyle, P.R., 1991. A review of methods for diet analysis in piscivorous marine mammals. Oceanogr. Mar. Biol. Annu. Rev. 29, 409-486.

110 Pierce, G.J., Santos, M.B., Ross, H.M., Reid, R.J., Patterson, A.I.P., Lopez, A., Cedeira 111 J., 2007. Diets of teuthophagous small cetaceans from the Scottish and Galician coasts. Poster, European Cetacean Society, San Sebastian, Spain.

113 Pierce, D.G.J., Caldas, M., Cedeira, J., Santos, M.B., Llavona, A., Covelo, P., Martinez, 114 G., Torres, J., Sacau, M., López, A., 2010. Trends in cetacean sightings along the Galician coast, north-west Spain, 2003-2007, and inferences about cetacean

117 Post, D.M., 2002. Using Stable Isotopes to Estimate Trophic Position: Models, Methods, $118 \quad$ and Assumptions. Ecology 83, 703-718.

119 Ringelstein, J., Pusineri, C., Hassani, S., Meynier, L., Nicolas, R., Ridoux, V., 2006. 120 Food and feeding ecology of the striped dolphin, Stenella coeruleoalba, in the 121 oceanic waters of the north-east Atlantic. J. Mar. Biol. Assoc. UK 86, 909-918. 
122 Ridoux, V., Lafontaine, L., Bustamante, P., Caurant, F., Dabin, W., Delcroix, C.,

123 Hassani, S., Meynier, L., Pereira da Silva, V., Simonin, S., Robert, M., Spitz, J., 124 Van Canneyt, O., 2004. The impact of the "Erika" oil spill on pelagic and coastal 125 marine mammals: Combining demographic, ecological, trace metals and 126 biomarker evidences. Aquat. Living Resour. 17, 379-387.

127 Ryther, J.H., 1969. Photosynthesis and fish production in the sea. Science 166, 72-76.

128 Santos, M.B., Clarke, M.R., Pierce, D.G.J., 2001. Assessing the importance of 129 cephalopods in the diets of marine mammals and other top predators: problems $130 \quad$ and solutions. Fish. Research. 52,121-139.

131 Santos, M.B., Learmonth, J.A., Pierce, G.J., Moffat, C.F., Rogan, E., Murphy, S., 132 Ridoux, V., Meynier, L., Lahaye, V., Pusineri, C., Spitz, J., 2004a. Dietary 133 Studies on Small Cetaceans in the NE Atlantic Using Stomach Contents and Fatty 134 Acid Analyses, BIOCET. University of Aberdeen, University College, Université 135 de La Rochelle, CRMM, Aberdeen, pp. 106.

136 Santos, M.B., Pierce, G.J., López, A., Martínez, J.A., Fernández, M.T., Ieno, E., Mente, 137 E., Porteiro, C., Carrera, P., Meixide, M., 2004b. Variability in the diet of 138 common dolphins (Delphinus delphis) in Galician waters 1991-2003 and 139 relationship with prey abundance. ICES CM 2004/ Q:09.

140 Santos, M.B., Fernandez, R., López, A., Martinez, J.A., Pierce, G.J., 2007a. Variability in 141 the diet of bottlenose dolphin, Tursiops truncatus, in Galician waters, north142 western Spain, 1990-2005. J. Mar. Biol. Assoc. UK 87, 231-241. 
143 Santos, M.B., Pierce, G.J., Ross, H.M., Reid, R.J., Patterson, A.I.P., López, A., Cedeira

144 J., 2007b. Diets of piscivorous small cetaceans from the Scottish and Galician 145 coasts. Poster, European Cetacean Society, San Sebastian, Spain.

146 Sherwood, G.D., Rose, G.A., 2005. Stable isotope analysis of some representative fish 147 and invertebrates of the Newfoundland and Labrador continental shelf food web. $148 \quad$ Estuar. Coast. Shelf Sci. 63, 537-549.

149 Sollmann, K., 2011. Diet and distribution of the bottlenose dolphin (Tursiops truncatus) 150 in Galicia, north-west Spain. MS dissertation, University of Aberdeen, Scotland.

151 Spitz, J., Richard, E., Meynier, L., Pusineri, C., Ridoux, V., 2006. Dietary plasticity of 152 the oceanic striped dolphin, Stenella coeruleoalba, in the neritic waters of the Bay 153 of Biscay. J. Sea Res. 55, 309-320.

154 Spitz, J., Cherel, Y., Bertin, S., Kiszka, J., Dewez, A., Ridoux, V., 2011. Prey preferences among the community of deep-diving odontocetes from the Bay of Biscay, Northeast Atlantic. Deep-Sea Res. Pt I 58, 273-282.

157 Spyrakos, E., Santos-Diniz, T.C., Martinez-Iglesias, G., Torres-Palenzuela, J.M., Pierce, 158 G.J., 2011. Spatiotemporal patterns of marine mammal distribution in coastal waters of Galicia, NW Spain. Hydrobiologia 670, 87-109.

160 Vander Zanden, M.J., Rasmussen, J.B., 2001. Variation in $\delta^{15} \mathrm{~N}$ and $\delta^{13} \mathrm{C}$ trophic 161 fractionation: Implications for aquatic food web studies. Limn. Oceanogr. 46, 162 2061-2066. 
163 Vanderklift, M., Ponsard, S., 2003. Sources of variation in consumer diet $\delta^{15} \mathrm{~N}$ 164 enrichment: a meta analysis. Oecologia 136, 169-182.

165 Walker, J., Macko, S.A., 1999. Dietary studies of marine mammals using stable carbon 166 and nitrogen isotopic ratios of teeth. Mar. Mam. Sci. 15, 314-334. 